\title{
Pengaruh Senam Si Buyung dan Senam Irama Ceria Terhadap Kemampuan Motorik Kasar
}

\author{
Iswatiningrum $^{1 凶}$, Panggung Sutapa $^{1}$ \\ Pendidikan Anak Usia Dini, Universitas Negeri Yogyakarta, Indonesia(1) \\ DOI: $\underline{10.31004 / o b s e s i . v 6 i 4.2373}$
}

\begin{abstract}
Abstrak
Kemampuan motorik kasar anak usia dini memiliki peran penting bagi perkembangan pribadi secara keseluruhan. Kemampuan motorik kasar ini dapat dikembangkan melalui beberapa cara, salah satunya menggunakan gerakan senam Si Buyung dan senam Irama Ceria. Tujuan penelitian adalah untuk menganalisis pengaruh senam Si Buyung dan Senam Irama Ceria terhadap kemampuan motorik kasar pada anak TK kelompok B. Jenis penelitian adalah penelitian eksperimen dengan desain one group-pretest-posttest design. Teknik sampling menggunakan purposive sampling. Penelitian dilakukan pada enam TK dengan jumlah sampel penelitian sebanyak 153 anak. Teknik pengumpulan data menggunakan lembar observasi dan dokumentasi. Teknik analisis data menggunakan Wilcoxon Test. Hasil penelitian menyimpulkan bahwa latihan senam Si Buyung dan senam Irama Ceria dapat meningkatkan kemampuan motorik kasar anak TK. Hal ini berimplikasi bahwa guru TK kelompok B dapat menggunakan senam Si Buyung dan senam Irama Ceria untuk meningkatkan kemampuan motorik anak.
\end{abstract}

Kata kunci: senam si buyung; senam irama ceria; motorik kasar

\begin{abstract}
Gross motor skills of early childhood have an important role for overall personal development. These gross motor skills can be developed in several ways, one of which is using Si Buyung's gymnastics and Irama Ceria's gymnastics. The purpose of the study was to analyze the effect of Si Buyung's gymnastics and Irama Ceria's gymnastics on gross motor skills in Kindergarten group B children. The type of research was experimental research with one group-pretestposttest design. The sampling technique used purposive sampling. The study was conducted in six Kindergarten with a total sample of 153 children. Data collection techniques using observation sheets and documentation. The data analysis technique used the Wilcoxon Test. The results of the study concluded that Si Buyung's gymnastics and Irama Ceria's gymnastics exercise could improve the gross motor skills of Kindergarten children. This implies that kindergarten teachers in group B can use Si Buyung's gymnastics and Irama Ceria's gymnastics to improve children's motor skills.
\end{abstract}

Keywords: si buyung's gymnastics, irama ceria's gymnastics, gross motor skills

Copyright (c) 2022 Iswatiningrum, et al.

$\square$ Corresponding author:

Email Address : iswatiningrum2@gmail.com (Yogyakarta, Indonesia)

Received 3 November 2021, Accepted 24 February 2022, Published 26 February 2022 


\section{PENDAHULUAN}

Motorik kasar merupakan suatu aktivitas fisik yang menggunakan seluruh otot-otot besar pada tubuh atau menggunakan sebagian besar otot yang ada dalam tubuh maupun seluruh anggota tubuh (Septiana \& Widiastuti, 2020). Motorik kasar ialah kegiatan yang melibatkan otot-otot besar dengan aktivitas menggunakan anggota seluruh tubuh, contoh berlari, melompat (Claudia et al., 2018). Perkembangan aspek motorik ini penting peranannya dalam kehidupan anak (Fitri \& Imansari, 2021).

Perkembangan motorik termasuk usaha untuk mengoptimalkan pertumbuhan dan perkembangan tubuh anak, sehingga dapat menudukung untuk mengoptimalkan perkembangan aspek yang lainnya. Hal ini karena kemampuan motorik kasar yang baik akan memberikan dapat positif terhadap tigkat kesehatan anak, karena anak akan gemar berolahraga dan melakukan gerakan-gerakan yang dapat memperbaiki sirkulasi darah, pernafasan, dan pembentukan postur tubuh yang ideal (Hayati, 2020). Keterampilan motorik menggambarkan berbagai kompetensi fisik, termasuk keseimbangan dan stabilitas, gerakan terkoordinasi, dan manipulasi objek (Nasution \& Sutapa, 2021). Keterampilan motorik kasar memerlukan beberapa unsur, diantaranya: kecepatan, kekuatan, ketahanan, kelincahan, fleksibilitas, koordinasi, dan keseimbangan (Fitri \& Imansari, 2021).

Aspek perkembangan anak dapat berkembang dengan baik apabila mendapat stimulus yang baik. Masa ini adalah masa emas (Golden Age) dalam mengembangkan kemampuan fisik, kognitif, bahasa, sosial, emosional, konsep diri, disiplin, kemandirian anak (Baan et al., 2020). Faktor-faktor yang mempengaruhi pertumbuhan dan perkembangan motorik yaitu faktor internal (perbedaan ras/ etnik atau bangsa, keluarga, umur, jenis kelamin, genetik, kelainan kromosom) dan faktor eksternal (gizi, mekanis, toksin/zat kimia, endokrin, radiasi. Infeksi, kelainan imunologi, anoksia embrio, psikologi ibu, faktor persalinan serta faktor pasca natal). Selain itu, pemberian stimulasi merupakan rangsangan yang datang dari lingkungan luar anak dan sangat penting dalam tumbuh kembang anak (Marischa, 2017).

Cara untuk mengoptimalkan perkembangan motorik kasar anak usia dini, yaitu melalui aktivitas bermain seperti bermain bola, menari, bermain perang-perangan, berolahraga, termasuk senam. Berdasarkan wawancara dengan guru di TK Pertiwi Tambak, TK Kristen Siwi Murti, TKIT MTA Karangndowo, TK ABA Ngolodono, TK ABA II, dan TK Pertiwi Bulusan diperoleh informasi bahwa: (1) ada dua guru yang pernah memberikan latihan senam Si Buyung kepada anak didik, (2) ada satu guru yang pernah memberikan latihan senam Si Buyung dan senam Irama Ceria kepada anak didik, dan (3) ada tiga guru yang belum pernah memberikan latihan senam Si Buyung dan senam Irama Ceria kepada anak didik. Temuan ini membuktikan bahwa senam Si Buyung dan senam Irama Ceria belum banyak digunakan oleh guru untuk meningkatkan motorik kasar anak secara intensif.

Senam merupakan salah satu olahraga yang dapat dijadikan sebagai salah satu alternatif untuk mengembangkan motorik kasar pada anak usia dini. Berbagai macam senam diantaranya senam si buyung, senam irama dan senam fantasi. Senam adalah suatu latihan tubuh yang dipilih dan dikonstruksi dan sengaja dilakukan secara sistematis dengan tujuan meningkatkan kesegaran jasmani, mengembangan keterampilan dan menanamkan nilai-nilai mental spiritual (Baan et al., 2020).

Berdasarkan pengamatan di TK/RA, permasalahan yang berkaitan dengan pembelajaran motorik kasar anak dapat didentifikasi sebagai berikut: (1) Kemampuan motorik kasar anak TK pada umumnya belum berkembangan secara maksimal, seperti anak belum terampil menggerakan tubuh mengikuti gerakan hewan atau mengikuti irama lagu; (2) Kreativitas guru TK dalam pembelajaran motorik kasar di TK masih kurang, karena bersifat monoton dengan memberikan latihan seperti: berlari, memanjat, melompat; (3) Sarana dan prasarana serta alat peraga pembelajaran senam di TK umumnya masih terbatas. Umumnya hanya menggunakan pelataran sekolah untuk berlari atau melompat, dan alat panjat yang terbuat dari besi; (4) Latihan senam Si Buyung dan Senam Irama Ceria belum banyak digunakan oleh guru untuk meningkatkan kemampuan motorik kasar anak TK; (5) 
Penggunaan audio visual dalam pembelajaran senam belum banyak digunakan oleh guru sebagai salah satu media pembelajaran dipandang cukup efektif untuk meningkatkan kemampuan motorik kasar anak, karena anak TK dapat menirukan gerakan yang ditunjukkan dalam audio visual. Di samping itu, audio visual dapat mendorong motivasi belajar anak.

Ada beberapa penelitian terdahulu yang relevan dengan penelitin ini. Penelitian Novitasari et al. (2019) dengan jurdul "Meningkatkan Kemampuan Motorik Kasar Anak Melalui Bermain Dengan Media Hulahoop Pada Anak Kelompok B PAUD Al-Syafaqoh Kabupaten Rejang Lebong" menyimpulkan bahwa kegiatan bermain dengan menggunakan hula hoop dapat meningkatkan kemampuan motorik kasar anak. Penelitian Verawati (2018) dengan judul "Peningkatan Keterampilan Motorik Kasar Anak Usia 4-5 Tahun Melalui Permainan Tradisional Tambi-Tambian Penelitian Tindakan Pada Kelompok A di TK Nasional KPS Balikpapan Tahun 2018" menyimpulkan bahwa permainan tradisional "Tambi-tambian" berkontribusi untuk meningkatkan keterampilan motorik kasar anak. Penelitian Isabela et al. (2021) dengan judul “Upaya Meningkatkan Kemampuan Motorik Kasar Anak Usia Dini Melalui Permainan Jump and Crawl, yang menyimpulkan bahwa permainan Jump and Crawl dapat menstimulasi perkembangan kemampuan melompat dan merangkak untuk pengembangan kemampuan anak. Penelitian Riswandi (2021) dengan judul "Peningkatan Kemampuan Motorik Kasar Melalui Pengembangan Model Permainan Sirkuit Anak Usia 5-6 Tahun" menyimpulkan bahwa model permainan sirkuit efektif dan layak digunakan guru dalam peningkatan kemampuan motorik kasar anak usia 5-6 tahun.

Selain penelitian dengan menggunakan bentuk permainan untuk meningkatkan kemampuan motrik kasar, ada peneliti yang menggunakan gerak lagu, senam irama, dan senam fantasi. Penelitian Prahesti \& Dewi (2020) yang berjudul "Gerak dan Lagu Neurokinestetik (GELATIK) untuk Menumbuhkan Kreativitas Seni Anak Usia Dini", yang menyimpulkan bahwa Gerak dan Lagu Neurokinestetik (GELATIK) dapat menumbuhkan kreativitas seni anak usia dini. Penelitian Tsaliska \& Maghfiroh (2020) dengan judul "Upaya Meningkatkan Motorik Kasar Anak Usia 5-6 Tahun Melalui Kegiatan Senam Irama", menyimpulkan bahwa kegiatan senam irama dapat menstimulus otot besarnya dan meningkatkan kualitas perkembangan dan pengontrolan fisiknya. Penelitian Martini (2012) dengan judul "Peningkatan Kemampuan Motorik Kasar Anak Melalui Senam Fantasi Di Taman Kanak Kanak Al Hikmah Lubuk Basung" menyimpulkan bahwa senam fantasi dapat mengembangkan motorik kasar anak di Taman Kanak-kanak Al Hikmah Lubuk Basung. Penelitian Syafril et al. (2020) dengan judul "Dua Cara Pengembangan Motorik Kasar Pada Anak Usia Dini Melalui Gerakan-Gerakan Senam" menyimpulkan bahwa Upaya guru yang dilakukan dalam mengembangkan kemampuan motorik kasar anak usia dini menghasilkan dua temuan penelitian yaitu ajak anak untuk bergerak dan koreksi jika anak melakukan kesalahan gerakan.

Berkaitan dengan permasalahan di atas maka tujuan penelitian ini adalah untuk menganalisis pengaruh senam Si Buyung dan Senam Irama Ceria terhadap kemampuan motorik kasar pada anak TK kelompok B. Penelitian ini memiliki perbedaan dengan penelitian sebelumnya, yaitu: (1) penelitian ini menggunakan senam Si Buyung dan senam Irama Ceria; (2) jenis penelitian adalah eksperimen; (3) sampel penelitian mengambil TK/RA yang berlokasi di dekat kantor Kecamatan, berlokasi di antara pelosok wilayah dan kantor Kecamatan, serta berlokasi di pelosok wilayah Kecamatan Karangdowo Kabupaten Klaten.

\section{METODOLOGI}

Jenis penelitian adalah penelitian eksperimen dengan desain one group-pretestposttest design. Teknik sampling menggunakan purposive sampling, dan penelitian dilakukan pada enam TK/RA dengan jumlah sampel penelitian sebanyak 153 peserta didik. Penelitian ini dilakukan di enam TK/RA dengan perincian yaitu: (1) Dua TK/RA yang berlokasi dekat dengan kantor Kecamatan Karangdowo Kabupaten Klaten, yaitu: TK Pertiwi Tambak jumlah murid 21 orang, dan TK Kristen Siwi Murti jumlah murid 36 orang; (2) Dua TK/RA yang 
berlokasi di antara pelosok wilayah dan kantor Kecamatan Karangdowo Kabupaten Klaten, yaitu TKIT MTA Karangndowo jumlah murid 25 orang, dan TK ABA Ngolodono jumlah murid 33 orang; (3) Dua TK/RA yang berlokasi di pelosok wilayah Kecamatan Karangdowo Kabupaten Klaten, yaitu TK ABA II Babadan jumlah murid 16 orang, dan TK Pertiwi Bulusan jumlah murid 22 orang.

Pada penelitian ini, kemampuan motorik kasar anak diukur dari 5 indikator, yaitu: (1) Kelenturan, merupakan kemampuan anak untuk melakukan aktivitas jasmani dengan gerakan sendi-sendi yang luas dan tidak kaku, yaitu kelenturan jasmani diukur dari kemampuan mencium lutut dalam posisi duduk (jumlah/menit); (2) Keseimbangan, yaitu kemampuan anak untuk mengontrol kerja alat tubuh yang bersifat neuromascular atau yang berhubungan dengan alat tubuh, serta untuk menjaga keseimbangan tubuh anak saat ditempatkan di berbagai posisi, yaitu keseimbangan berjalan di atas balok titian 4 meter yang diukur dari waktu tempuh (detik); (3) Kecepatan, yaitu kecepatan anak untuk bergerak dalam waktu yang singkat, yaitu berlari menempuh jarak 25 meter dan diukur dalam waktu (menit); (4) Kelincahan, yaitu kemampuan anak untuk melakukan gerak merubah arah secara efektif dan cepat tanpa kehilangan keseimbangan, yaitu kelincahan lari belak belok 4 meter yang diukur dari waktu tempuh (menit); (5) Kekuatan, yaitu kemampuan anak mengeluarkan tenaga atau kekuatan maksimal, yaitu melempar bola dan diukur dengan jarak lemparan (meter). Teknik pengumpulan data menggunakan lembar observasi (pengamatan) dan studi pustaka (dokumentasi). Teknik analisis data menggunakan analisis deskriptif, dan independent t-test (apabila data terdistribusi normal) atau Wilcoxon Test (apabila data tidak terdistribusi normal). Jika p-value $<0,05$ berarti ada perbedaan signifikan antara niai pretest dengan posttest.

\section{HASIL DAN PEMBAHASAN}

\section{Kemampuan Motorik Kasar Anak pada Pretest}

Sebelum diberikan latihan senam Si Buyung dan senam Irama Ceria, kemampuan motorik kasar anak disajikan pada tabel dan gambar 1 . Pada tabel dan gambar 1 diketahui bahwa dari 153 anak terdapat 27 anak (18\%) memperoleh nilai dengan kategori baik sekali, ada 65 anak (42\%) memperoleh nilai dengan kategori baik, ada 43 anak (28\%) memperoleh nilai dengan kategori cukup, dan ada 18 anak (12\%) memperoleh nilai dengan kategori kurang. Dari temuan ini diketahui bahwa sebagian besar anak telah memiliki kemampuan motorik kasar dengan kategori baik sebelum diberikan latihan senam Si Buyung dan senam Irama Ceria.

\section{Tabel 1. Kemampuan Motorik Kasar Anak Sebelum Diberikan Latihan Si Buyung dan Senam} Irama Ceria (Pretest)

\begin{tabular}{clcc}
\hline Nilai & Kategori & Jumlah & Persentase \\
\hline $80-100$ & Baik sekali & 27 & $18 \%$ \\
$66-79$ & Baik & 65 & $42 \%$ \\
$56-65$ & Cukup & 43 & $28 \%$ \\
$40-55$ & Kurang & 18 & $12 \%$ \\
$0-39$ & Sangat kurang & 0 & $0 \%$ \\
\hline \multicolumn{2}{c}{ Jumlah } & 153 & $100 \%$ \\
\hline
\end{tabular}




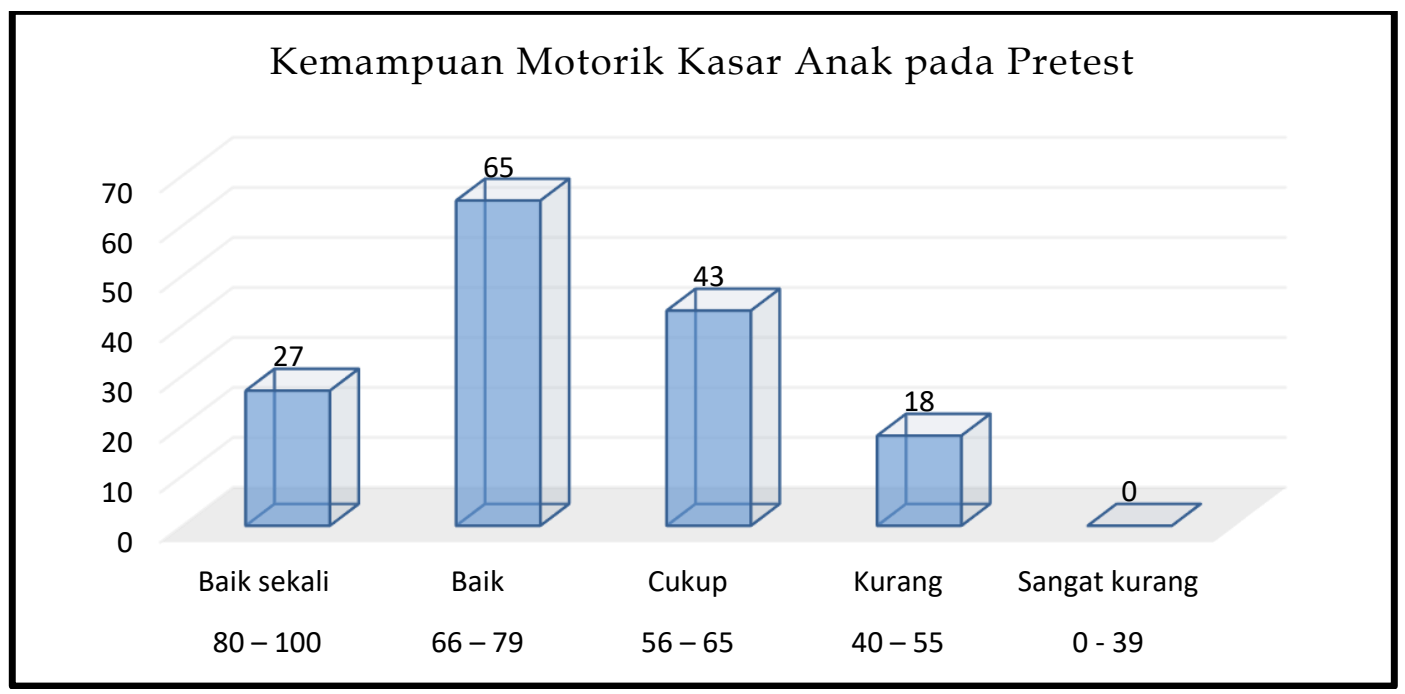

\section{Gambar 1 Kemampuan Motorik Kasar Anak Sebelum Diberikan Latihan Si Buyung dan Senam} Irama Ceria (Pretest)

\section{Kemampuan Motorik Kasar Anak pada Posttest}

Sesudah diberikan latihan senam Si Buyung dan senam Irama Ceria selam 6 kali (hari) @ 30 menit, kemampuan motorik kasar anak disajikan pada tabel dan gambar 2.

Tabel 2 Kemampuan Motorik Kasar Anak Sesudah Diberikan Latihan Si Buyung dan Senam Irama Ceria (Posttest)

\begin{tabular}{clcc}
\hline Nilai & Kategori & Jumlah & Persentase \\
\hline $80-100$ & Baik sekali & 35 & $23 \%$ \\
$66-79$ & Baik & 67 & $44 \%$ \\
$56-65$ & Cukup & 42 & $27 \%$ \\
$40-55$ & Kurang & 9 & $6 \%$ \\
$0-39$ & Sangat Kurang & 0 & $0 \%$ \\
\hline \multicolumn{2}{c}{ Jumlah } & 153 & $100 \%$ \\
\hline
\end{tabular}

Kemampuan Motorik Kasar Anak pada Posttest

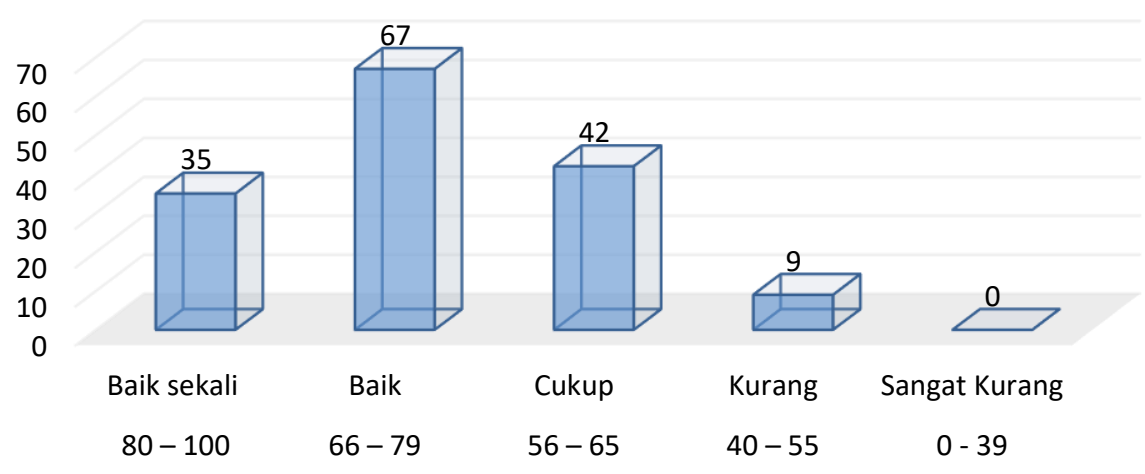

Gambar 2 Kemampuan Motorik Kasar Anak Sesudah Diberikan Latihan Si Buyung dan Senam Irama Ceria (Posttest)

Pada tabel dan gambar 2 diketahui bahwa dari 153 anak terdapat 27 anak (18\%) memperoleh nilai dengan kategori baik sekali, ada 65 anak (42\%) memperoleh nilai dengan kategori baik, ada 43 anak (28\%) memperoleh nilai dengan kategori cukup, dan ada 18 anak $(12 \%)$ memperoleh nilai dengan kategori kurang. Dari temuan ini diketahui bahwa sebagian 
besar anak telah memiliki kemampuan motorik kasar dengan kategori baik sesudah diberikan latihan senam Si Buyung dan senam Irama Ceria.

\section{Perbandingan Kemampuan Motorik Kasar Anak antara Pretest dan Posttest}

Untuk mengetahui ada-tidaknya peningkatan kemampuan motorik kasar anak sebelum dan sesudah diberikan latihan senam Si Buyung dan senam Irama Ceria, maka nilai pretest dan posttest kemampuan motorik kasar anak dapat dibandingkan sebagaimana disajikan pada tabel dan gambar 3 .

Tabel 3 Perbandingan Kemampuan Motorik Kasar Anak Sebelum dan Sesudah Diberikan Latihan Si Buyung dan Senam Irama Ceria (Pretest-Posttest)

\begin{tabular}{clcccc}
\hline \multirow{2}{*}{ Nilai } & \multirow{2}{*}{ Kategori } & \multicolumn{2}{c}{ Nilai Pretest } & \multicolumn{2}{c}{ Nilai Posttest } \\
\cline { 3 - 6 } & & Jumlah & Persentase & Jumlah & Persentase \\
\hline $80-100$ & Baik sekali & 27 & $18 \%$ & 35 & $23 \%$ \\
$66-79$ & Baik & 65 & $42 \%$ & 67 & $44 \%$ \\
$56-65$ & Cukup & 43 & $28 \%$ & 42 & $27 \%$ \\
$40-55$ & Kurang & 18 & $12 \%$ & 9 & $6 \%$ \\
$0-39$ & Sangat kurang & 0 & $0 \%$ & 0 & $0 \%$ \\
\hline \multicolumn{2}{c}{ Jumlah } & 153 & $100 \%$ & 153 & $100 \%$ \\
\hline
\end{tabular}

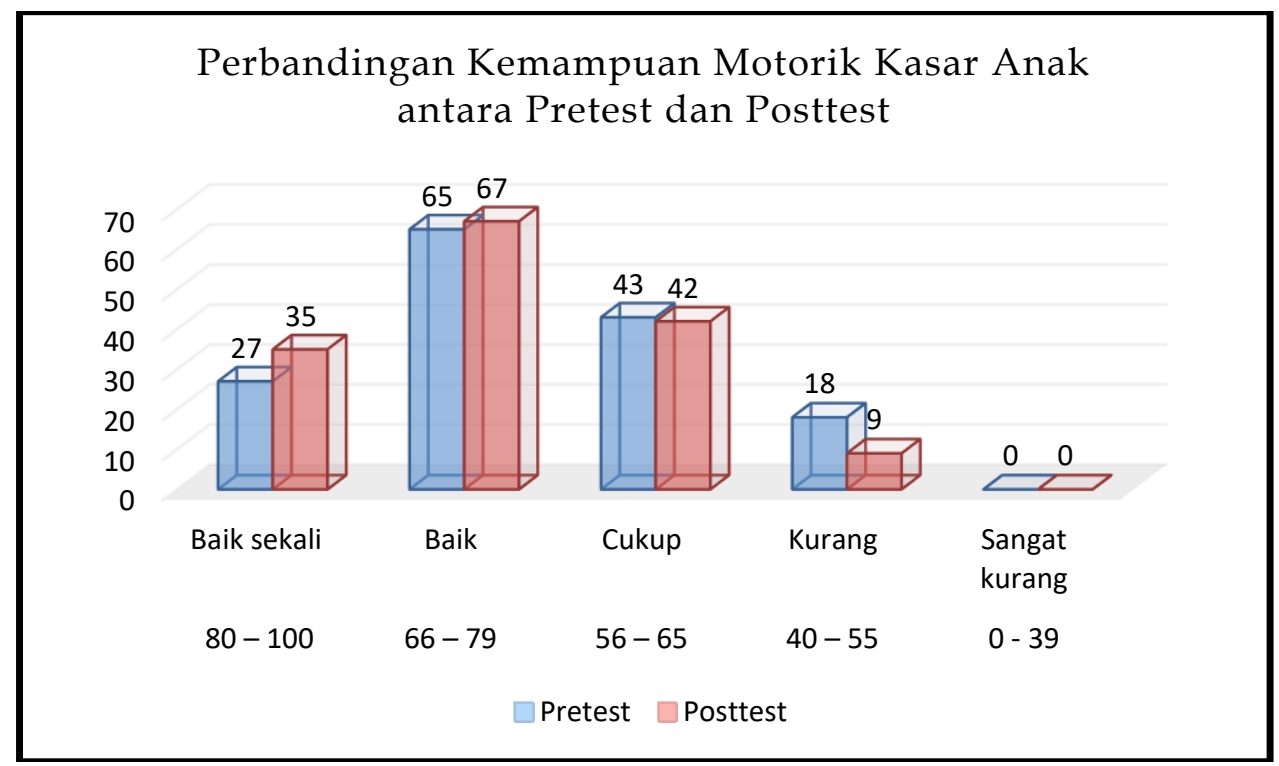

\section{Gambar 3 Perbandingan Kemampuan Motorik Kasar Anak Sebelum dan Sesudah Diberikan Latihan Si Buyung dan Senam Irama Ceria (Pretest-Posttest)}

Pada tabel dan gambar 3 diketahui bahwa dari 153 anak terdapat 27 anak (18\%) memperoleh nilai dengan kategori baik sekali sebelum diberikan latihan senam Si Buyung dan senam Irama Ceria, kemudian sesudah diberikan latihan senam Si Buyung dan senam Irama Ceria meningkat menjadi 35 anak (23\%). Ada 65 anak (42\%) memperoleh nilai dengan kategori baik sebelum diberikan latihan senam Si Buyung dan senam Irama Ceria, kemudian sesudah diberikan latihan senam Si Buyung dan senam Irama Ceria meningkat menjadi 67 anak (44\%). Ada 43 anak (28\%) memperoleh nilai dengan kategori cukup sebelum diberikan latihan senam Si Buyung dan senam Irama Ceria, kemudian sesudah diberikan latihan senam Si Buyung dan senam Irama Ceria berkurang menjadi 42 anak (27\%), artinya ada beberapa anak meningkat nilainya dari pretest ke posttest-nya. Ada 18 anak (12\%) memperoleh nilai dengan kategori kurang sebelum diberikan latihan senam Si Buyung dan senam Irama Ceria, kemudian sesudah diberikan latihan senam Si Buyung dan senam Irama Ceria berkurang 
menjadi 9 anak (6\%), artinya ada beberapa anak meningkat nilainya dari pretest ke posttestnya. Dengan demikian, kemampuan motorik anak sesudah diberikan latihan senam Si Buyung dan senam Irama Ceria lebih baik dibandingkan dengan sebelum diberikan latihan senam Si Buyung dan senam Irama Ceria.

\section{Analisis Statistik}

\section{Uji Normalitas Data}

Teknik analisis data yang digunakan untuk membandingkan atau menganalisis perbedaan nilai pretest dengan posttest menggunakan Paired $t$-test (apabila data terdistribusi normal) atau Wilcoxon (apabila data terdistribusi normal). Berdasarkan hasil uji normalitas data dengan Kolmogorov-Smirnov diperoleh hasil sebagaimana disajikan pada tabel 4 .

Tabel 4 Hasil Uji Normalitas Data One-Sample Kolmogorov-Smirnov Test

\begin{tabular}{llr|r}
\hline & & Nilai_pretest & Nilai_posttest \\
\hline N & & 153 & 153 \\
\hline \multirow{2}{*}{ Normal Parameters ${ }^{\mathrm{a}, \mathrm{b}}$} & Mean & 66,4052 & 69,2026 \\
\cline { 2 - 4 } & Std. Deviation & 11,87071 & 10,08475 \\
\hline \multirow{2}{*}{ Most Extreme Differences } & Absolute &, 155 &, 162 \\
\cline { 2 - 4 } & Positive &, 133 &, 162 \\
\cline { 2 - 4 } & Negative &,- 155 &,- 119 \\
\hline Test Statistic & &, 155 &, 162 \\
\hline Asymp. Sig. (2-tailed) & &, $000^{c}$ &, $000^{c}$ \\
\hline
\end{tabular}

a. Test distribution is Normal.

b. Calculated from data.

c. Lilliefors Significance Correction.

Pada tabel 4 diketahui bahwa angka Test Statistic untuk nilai Pretest adalah 0,155 dengan signifikansi $0,000<0,05$ berarti data nilai Pretest tidak terdistribusi normal, dan angka Test Statistic untuk nilai Posttest adalah 0,162 dengan signifikansi $0,000<0,05$ berarti data nilai Posttest juga tidak terdistribusi normal. Oleh karena itu, untuk menguji perbedaan nilai Pretest dengan Posttest menggunakan Wilcoxon.

\section{Uji Wilcoxon}

Berdasarkan hasil uji Wilcoxon diperoleh hasil sebagaimana disajikan pada tabel 5.

Tabel 5 Hasil Uji Perbedaan Nilai Pretest dengan Posttest

\begin{tabular}{llr|r|r}
\hline \multicolumn{5}{c}{ Ranks } \\
\hline \multirow{2}{*}{ Nilai_posttest - Nilai_pretest } & N & Mean Rank & Sum of Ranks \\
\cline { 2 - 5 } & Negative Ranks & $0^{\text {a }}$ &, 00 &, 00 \\
\cline { 2 - 5 } & Positive Ranks & $68^{\mathrm{b}}$ & 34,50 & 2346,00 \\
\cline { 2 - 5 } & Ties & $85^{\mathrm{c}}$ & & \\
\cline { 2 - 5 } & Total & 153 & & \\
\hline
\end{tabular}

a. Nilai_posttest $<$ Nilai_pretest
b. Nilai_posttest $>$ Nilai_pretest
c. Nilai_posttest $=$ Nilai_pretest

Test Statistics ${ }^{a}$

Nilai_posttest - Nilai_pretest

\begin{tabular}{lr}
\hline$Z$ & $-7,410^{\mathrm{b}}$ \\
\hline Asymp. Sig. (2-tailed) &, 000 \\
\hline
\end{tabular}

a. Wilcoxon Signed Ranks Test

b. Based on negative ranks. 
Pada tabel 5 diketahui bahwa mean Rank antara nilai Pretest dan Posttest adalah 34,50 dengan angka $Z$ sebesar -7,410 dengan signifikansi $0,000<0,05$ berarti antara nilai Pretest dengan nilai Posttest terdapat perbedaan signifikan. Artinya, rata-rata kemampuan motorik kasar anak sebelum (Pretest) dan sesudah (Posttest) diberikan latihan senam Si Buyung dan senam Irama Ceria terdapat perbedaan signifikan (nyata). Dengan kata lain, latihan senam Si Buyung dan senam Irama Ceria dapat meningkatkan kemampuan motorik kasar anak.

\section{Pembahasan}

Berdasarkan hasil penelitian seperti yang telah diuraikan di atas, diketahui bahwa kemampuan motorik anak sesudah diberikan latihan senam Si Buyung dan senam Irama Ceria lebih baik dibandingkan dengan sebelum diberikan latihan senam Si Buyung dan senam Irama Ceria. Anak yang memperoleh nilai dengan kategori baik sekali sebelum diberikan latihan senam Si Buyung dan senam Irama Ceria (18\%), sesudah diberikan latihan senam Si Buyung dan senam Irama Ceria meningkat menjadi $23 \%$ anak. Sebanyak $42 \%$ anak memperoleh nilai dengan kategori baik sebelum diberikan latihan senam Si Buyung dan senam Irama Ceria, kemudian sesudah diberikan latihan senam Si Buyung dan senam Irama Ceria meningkat menjadi $44 \%$ anak. Artinya ada beberapa anak meningkat nilainya dari pretest ke posttest-nya.

Berdasarkan hasil uji Wilcoxon diketahui bahwa rata-rata kemampuan motorik kasar anak sebelum (Pretest) dan sesudah (Posttest) diberikan latihan senam Si Buyung dan senam Irama Ceria terdapat perbedaan signifikan (nyata). Dengan kata lain, latihan senam Si Buyung dan senam Irama Ceria dapat meningkatkan kemampuan motorik kasar anak. Hasil penelitian ini mendukung penelitian Eriani \& Dimyati (2020) yang menyimpulkan bahwa senam si buyung dirancang agar dapat memberikan kebebasan bergerak sesuai dengan imajinasi, sehingga mendorong anak-anak untuk mengalami, menemukan, dan belajar dengan caranya sendiri. Selain itu anak-anak dapat mengekespresikan diri dengan menggerakan tubuh untuk mengekspresikan ide, pikiran, dan emosi. Senam si buyung adalah senam untuk anak usia dini yang dilakukan dengan cara merealisasikan imajinasi atau fantasi ke dalam gerakan. Berdasarkan teknik analisis kruskal wallis nilai sig. sebesar 0,00 yang memenuhi asumsi sig.< 0,05 maka dapat disimpulkan bahwa ada peningkatan kreativitas gerak pada anak usia 4-5 tahun. Senam si buyung efektif untuk meningkatkan kreativitas gerak anak usia 4-5 tahun. Hasil penelitian (Kustati et al., 2016) menyimpulkan bahwa dengan pembelajaran senam ritmik Si Buyung dengan menggunakan lagu Potong Bebek Angsa mampu meningkatkan hasil belajar siswa dalam materi pembelajaran senma ritmik si buyung. Baan et al. (2020) menyatakan bahwa senam fantasi (Si Buyung) berpengaruh secara signifikan terhadap gerakan motorik kasar anak khususnya gerak lokomotor seperti berjalan berjinjit, meloncat dan melompat.

Penelitian serupa yang mendukung penelitian ini adalah penelitian yang menggunakan senam irama ceria untuk meningkatkan kemampuan motorik kasar anak. Hasil penelitian Zulfah (2019) menyimpulkan bahwa senam ceria dapat meningkatkan minat siswa terhadap kegiatan fisik motorik. Hasil penelitian (Subhan \& Irfah, 2019) menyimpulkan bahwa penerapan senam ceria mampu meningkatkan keterampilan motorik kasar pada anak TK kelompok B. Hasil penelitian (Nuryanti et al., 2015) menyimpulkan bahwa melalui kegiatan senam ceria kemampuan motorik kasar anak meningkat. Penelitian Hartini dan Abubakar juga menyimpulkan bahwa video senam ceria sangat layak dan sangat efektif sebagai media pembelajaran untuk meningkatkan ketrampilan motorik kasar siswa down syndrome (Hartina \& Abubakar, 2019). Penelitian Wijayanti dkk menyimpulkan keterampilan motorik kasar anak dapat ditingkatkan melalui kegiatan senam irama (Wijayanti et al., 2020). Penelitian Sukma \& Wafi menyimpulkan kegiatan senam irama dalam meningkatkan kemampuan motorik kasar anak (Sukma \& Wafi, 2018). Penelitian Alfah \& Putra menyimpulkan penerapan senam irama dalam meningkatkan kemampuan motorik kasar anak usia dini. Semakin banyak kegiatan yang bervariatif dan inovatif maka peluang untuk 
meningkatkan kemampuan motorik kasar pada anak sehingga dapat berkembang dengan optimal (Ulfah \& Putra, 2021). Penelitian Nuryanti et al. (2015) menyimpulkan bahwa senam ceria dapat meningkatkan kemampuan motorik kasar anak.

Penelitian lain yang relevan dengan penelitian ini adalah penelitian Ubaedah et al. (2019) yang menyimpulkan bahwa melalui kegiatan senam irama binatang dapat meningkatkan keterampilan motorik kasar anak usia 5-6 tahun. Penelitian Nirwana \& Hiliani (2021) menyimpulkan bahwa aspek motorik kasar pada anak usia 5-6 tahun khususnya pada indikator daya tahan, keseimbangan, dan kelincahan dapat ditingkatkan melalui senam irama. Peningkatan kemampuan aspek motorik kasar anak dapat diamati dari adanya peningkatan persentase skor pada saat pra-siklus dan pasca-siklus. Skor-rata-rata pra-siklus yaitu $21,83 \%$ meningkat hingga $57,16 \%$ pada siklus I. Skor tersebut terus mengalami peningkatan hingga $79,05 \%$ pada siklus II dan dinyatakan telah mencapai kriteria kerberhasilan yaitu $75 \%$.

Senam si Buyung dan senam Irama Ceria yang didukung dengan penggunaan audio visual dapat meningkatkan kecerdasan kinestetik pada anak. Penelitian Lastari et al. (2016) menyimpulkan bahwa penerapan pembelajaran gerak dan lagu berbantuan audio visual dapat meningkatkan kecerdasan kinestetik pada anak kelompok B. Penelitian Zakaria (2014) menyimpulkan bahwa ada pengaruh penggunaan media audio visual terhadap kecerdasan kinestetik pada anak kelompok B.

Senam merupakan aktivitas fisik yang dapat membantu mengoptimalkan perkembangan motorik anak. Gerakan-gerakan senam sangat sesuai untuk meningkatkan kekuatan dan daya tahan otot dari seluruh bagian tubuh. Kegiatan senam Si Buyung yang berisikan gerakan-gerakan tubuh yang sederhana dan dikemas secara menarik melalui gerakan-gerakan unik seperti hewan berjalan, melambai tertiup angin, atau bahkan menirukan gerakan alat transportasi ketika sedang melaju di jalanan. Sedangkan gerakan senam dalam senam ceria pada dasarnya gabungan dari banyak gerakan yang diiringi dengan irama musik yang membuat gairah, sehingga hal tersebut menarik perhatian para siswa untuk mengikuti iramanya (Sukma \& Wafi, 2018). Pembelajaran senam melalui gerak dan lagu pada anak usia dini sangat bermanfaat untuk merangsang perkembangan anak, khususnya perkembangan fisik dan motorik anak. Hasil penelitian Pradipta \& Sukoco menyimpulkan bahwa Senam Si Buyung melalui gerak dan lagu adalah aktivitas yang sangat menyenangkan bagi anak TK, aktivitas gerak dan lagu memberi sumbangan yang besar untuk perkembangan otak anak TK (Pradipta \& Sukoco, 2013).

Senam fantasi ( $\mathrm{Si}$ Buyung) dapat dijadikan sebagai bentuk latihan untuk mengembangan motorik kasar anak usia dini. Senam fantasi yang dapat diterapkan seperti senam fantasi bentuk meniru tanpa alat, senam fantasi meniru dengan alat, dan senam fantasi dalam bentuk cerita (Baan et al., 2020). Senam Si Buyung adalah salah satu cabang dari senam ritmik yang di dalamnya ada unsur gerak dan irama, yang akan ditujukan untuk perkembangan sistem syaraf sensoris pada anak usia dini (Mawarti et al., 2010). Samsudin menjelaskan senam kanak-kanak (biasa disebut senam Si Buyung) ini dapat dilaksanakan dengan berbagai cara salah satunya dengan senam menurut fantasi (anak meniru gerak-gerik atau tingkah laku manusia, binatang, serta gerakan benda-benda) (Samsudin, 2008). Kegiatan ini merupakan kegiatan senam yang berisikan gerakan-gerakan tubuh yang sederhana dan dikemas secara menarik melalui gerakan-gerakan unik seperti hewan berjalan, melambai tertiup angin, atau bahkan menirukan gerakan alat transportasi ketika sedang melaju di jalanan (Baan et al., 2020).

Keterampilan motorik menggambarkan berbagai kompetensi fisik, termasuk keseimbangan dan stabilitas, gerakan terkoordinasi, dan manipulasi objek (Nasution \& Sutapa, 2021). Physical activity (PA) sudah menjadi bagian yang sangat penting untuk proses perkembangan anak baik untuk meningkatkan kesehatan, kardiovaskuler dan sebagai sarana mereka untuk melakukan sosialisasi dengan teman sebayanya (Utoyo et al., 2021). Elemen dasar gerak yang membentuk keterampilan motorik adalah kekuatan, kelincahan, 
keseimbangan, dan koordinasi. Keterampilan gerakan dasar merupakan bagian penting untuk perkembangan motorik seumur hidup sehingga dianggap sebagai pondasi penting untuk keterampilan olahraga dikemudian hari (Wulandari \& Asmawi, 2021).

Ada beberapa manfaat yang anak peroleh setelah melakukan senam irama, yaitu: (1) Meningkatkan kelentukan, keseimbangan, koordinasi, kelincahan, daya tahan, dan sanggup melakukan kegiatan-kegiatan atau olahraga lainnya; (2) Dapat membakar lemak yang berlebihan, meningkatkan daya tahan jantung dan paru-paru; (3) Senam irama merupakan salah satu jenis senam yang dapat digunakan untuk program penurunan berat badan; (4) Jika berlatih dengan ringan akan meningkatkan nafsu makan, dan jika berlatih dengan berat akan menekan rasa lapar karena banyak darah yang beredar di daerah otot yang aktif dan bukan di daerah perut; (5) Setelah melakukan senam irama, tubuh sehat dan hati riang karena pengaruh alunan musik. (Prahesti \& Dewi, 2020).

Penelitian ini memiliki keterbatasan seperti: (1) desain peneitian menggunakan one group-pretest-posttest design, sehingga tidak menggunakan kelompok kontrol, (2) pengambilan sampel menggunakan purposive sampling, dan tidak memberikan kesempatan yang sama pada setiap anggota populasi untuk dijadikan sampel.

\section{SIMPULAN}

Latihan senam Si Buyung dan senam Irama Ceria dapat meningkatkan kemampuan motorik kasar anak, karena rata-rata kemampuan motorik kasar anak sebelum (Pretest) dan sesudah (Posttest) diberikan latihan senam Si Buyung dan senam Irama Ceria terdapat perbedaan signifikan (nyata). Senam Si Buyung dan senam Irama Ceria dapat meningkatkan kemmapuan motorik kasar anak, karena gerakan senam menggerakan otot-otot besar. Gerakan senam juga mudah ditirukan oleh anak karena gerakan senam menirukan gerakan binatang. Selian itu, anak juga senang mengikuti latihan senam Si Buyung dan senam Irama Ceria yang diberikan dengan bantuan audio visual, karena suasana pembelajaran menjadi semarak. Hal ini berimplikasi bahwa guru TK kelompok B dapat menggunakan senam Si Buyung dan senam Irama Ceria untuk meningkatkan kemampuan motorik anak.

\section{UCAPAN TERIMA KASIH}

Peneliti mengucapkan terima kasih kepada kepala sekolah, guru dan orang tua anak yang telah berpartisipasi aktif membantu pengisian kuesioner.

\section{DAFTAR PUSTAKA}

Baan, A. B., Rejeki, H. S., \& Nurhayati. (2020). Perkembangan Motorik Kasar Anak Usia Dini. Jurnal Bungamputi, 6(1), 14-21.

Claudia, S., Widiastuti, A. A., Kurniawan, M., Paud, P. G., Kristen, U., \& Wacana, S. (2018). Jurnal Obsesi : Jurnal Pendidikan Anak Usia Dini Origami Game for Improving Fine Motor Skills for Children 4-5 Years Old in Gang Buaya Village in Salatiga. 2(2), 143148. https://doi.org/10.31004/obsesi.v2i2.97

Eriani, E., \& Dimyati. (2020). Stimulasi Kreativitas Gerak Anak Melalui Senam Si Buyung. Mitra Ash-Shibyan, Jurnal Pendidikan Dan Konseling, 3(2), 88-97. https:// doi.org/10.46963/mash.v3i02.159

Fitri, R., \& Imansari, M. L. (2021). Permainan Karpet Engkle: Aktivitas Motorik untuk Meningkatkan Keseimbangan Tubuh Anak Usia Dini. 5(2), 1187-1198. https:// doi.org/10.31004/obsesi.v5i2.754

Hartina, W. O., \& Abubakar, S. R. (2019). Meningkatkan Keterampilan Motorik Kasar Anak Melalui Kegiatan Senam Irama. Jurnal Riset Golden Age PAUD UHO, 2(1). https://doi.org/10.36709/jrga.v2i1.8309

Hayati, S. (2020). Tangkas Fisik-Motorik dengan Permainan Tradisional. Pustaka pelajar. 
Isabela, N. I., Dwiyanti, L., \& Ridwan. (2021). Upaya meningkatkan kemampuan motorik kasar anak usia dini melalui permainan jump and crawl. Seling: Jurnal Program Studi PGRA, 7, 1-10.

Kustati, U., Hartiwan, \& Supriyono. (2016). Peningkatan Hasil Belajar Senam Ritmik Si Buyung Menggunakan Lagu Potong Bebek Angsa Kelas 1 SD Negeri 1 Notog Kecamatan Patikraja Kabupaten Banyumas Tahun Ajaran 2016. Journal of Physical Education, Health and Sport, JPEHS, 3(1), 32-42.

Lastari, A. A. I. I. A., Gading, I. K., \& Antara, P. A. (2016). Penerapan Pembelajaran Gerak Dan Lagu BerbantuanAudiovisual Untuk Meningkatkan KecerdasanKinestetik Pada Anak Kelompok B. E-JournalPendidikan Anak Usia Dini Universitas Pendidikan Ganesha, JurusanPendidikan Guru Pendidikan Anak Usia Dini, 4(2), 1-10.

Marischa, S. (2017). Analisis Tingkat Pengetahuan Orang Tua tentang Stimulasi dengan Perkembangan Motorik Kasar Anak Usia 0-5 Tahun. J Agromed Unila, 2(4), 452-455.

Martini. (2012). Peningkatan Kemampuan Motorik Kasar Anak Melalui Senam Fantasi Di Taman Kanak Kanak Al Hikmah Lubuk Basung. Jurnal Pesona PAUD Vol.1.No.1., 1(1), $1-12$.

Mawarti, S., Sukamti, E. R., \& Prasetyo, Y. (2010). Pembuatan Paket Senam Si Buyung untuk Guru-guru TK. UNY.

Nasution, S. T., \& Sutapa, P. (2021). Strategi Guru dalam Menstimulasi Keterampilan Motorik AUD Pada Era Pandemi Covid $19 . \quad 5(2), \quad$ 1313-1324. https://doi.org/10.31004/obsesi.v5i2.849

Nirwana, \& Hiliani, R. (2021). Peningkatkan kemampuan motorik kasar melalui latihan senam irama dengan alat. Yasmin: Jurnal Pendidikan Anak Usia Dini, 2(1), 1-7. https://doi.org/10.23960/jiip.v2i1.21785

Novitasari, R., Nasirun, M., \& Delrefi D. (2019). Meningkatkan Kemampuan Motorik Kasar Anak Melalui Bermain Dengan Media Hulahoop Pada Anak Kelompok B Paud AlSyafaqoh Kabupaten Rejang Lebong. Jurnal Ilmiah Potensia, 4(1), 6-12. https://doi.org/10.33369/jip.4.1.6-12

Nuryanti, Roni, R., \& Ismail, H. (2015). Pengembangan Kemampuan Motorik Kasar Anak Melalui Kegiatan Senam Ceria. Cakrawala Dini, 5(2), 101-111.

Pradipta, G. D., \& Sukoco, P. (2013). Model Senam Si Buyung Untuk Pembelajaran Motorik Kasar Pada Siswa Taman Kanak-Kanak. Jurnal Keolahragaan, 1(1), 130-141. https://doi.org/10.21831/jk.v1i2.2569

Prahesti, S. I., \& Dewi, N. K. (2020). Jurnal Obsesi : Jurnal Pendidikan Anak Usia Dini Gerak dan Lagu Neurokinestetik ( GELATIK) untuk Menumbuhkan Kreativitas Seni Anak Usia Dini Abstrak. 4(1), 162-171. https://doi.org/10.31004/obsesi.v4i1.289

Riswandi, F. N. (2021). Peningkatan Kemampuan Motorik Kasar Melalui Pengembangan Model Permainan Sirkuit Anak Usia 5-6 Tahun. Jurnal PG-PAUD Trunojoyo : Jurnal Pendidikan Dan Pembelajaran Anak Usia Dini, 8(1), 66-78. https://doi.org/10.21107/pgpaudtrunojoyo.v8i1.10233

Samsudin. (2008). Pembelajaran Motorik di Taman Kanak-kanak. Litera Prenada Media Group.

Septiana, V. T., \& Widiastuti, A. A. (2020). Jurnal Obsesi : Jurnal Pendidikan Anak Usia Dini Dukungan Orang Tua dalam Mengembangkan Motorik Kasar Anak Cerebral Palsy pada Anak Usia Dini Abstrak Abstract: 4(1), 172-180. https://doi.org/10.31004/obsesi.v4i1.298

Subhan, \& Irfah, A. (2019). Kreasi Senam Ceria Pada Taman Kanak-Kanak Meningkatkan Keterampilan Motorik Kasar Anak Usia Dini Berbasis Gerak dan Lagu. Jurnal Tunas Cendekia, 2(2), 70-78.

Sukma, T., \& Wafi, A. (2018). Peningkatkan Ketrampilan Motorik Kasar Siswa Down $\begin{array}{lllll}\text { Syndrome melalui } & \text { Senam } & \text { 43-47. }\end{array}$ https://doi.org/10.17977/um031v4i12018p043 
Syafril, S., Kuswanto, C. W., \& Muriyan, O. (2020). Dua Cara Pengembangan Motorik Kasar Pada Anak Usia Dini Melalui Gerakan-Gerakan Senam. Jurnal Upmk, 5(1), 104-113. https:// doi.org/10.30651/pedagogi.v5i1.2517

Tsaliska, S., \& Maghfiroh. (2020). Upaya Meningkatkan Motorik Kasar Anak Usia 5-6 Tahun Melalui Kegiatan Senam Irama. Jurnal Care, 8(1), 40-47.

Ubaedah, D., Fatimah, A., \& Kusumawardani, R. (2019). Meningkatkan keterampilan motorik kasar melalui senam irama binatang. JPP PAUD FKIP Untirta, 6(1), 29-40.

Ulfah, A. A., \& Putra, A. J. A. (2021). Analisis Penerapan Senam Irama dalam Meningkatkan Kemampuan Motorik Kasar Anak Usia Dini. 5(2), 1844-1852. https:// doi.org/10.31004/obsesi.v5i2.993

Utoyo, S., Juniarti, Y., Sari, N., \& Mangge, K. (2021). Jurnal Obsesi : Jurnal Pendidikan Anak Usia Dini Pendidikan Jasmani Untuk Anak Usia Dini : Pengembangan Fundamental Movement Skill ( FMS ) pada Anak Abstrak. 5(1), 404-413. https://doi.org/10.31004/obsesi.v5i1.605

Verawati, I. (2018). Peningkatan Keterampilan Motorik Kasar Anak Usia 4-5 Tahun Melalui Permainan Tradisional Tambi-Tambian Penelitian Tindakan Pada Kelompok A di TK Nasional KPS Balikpapan Tahun 2018. Jurnal PAUD Agapedia, 2(1), 66-75. https:// doi.org/10.17509/jpa.v2i1.24389

Wijayanti, A., Wijayanti, A., \& Laksono, B. A. (2020). Peningkatan Kemampuan Motorik Kasar melalui Kegiatan Senam Irama. Jurnal Inovatif Ilmu Pendidikan, 2(1), 1-14. https://doi.org/10.23960/jiip.v2i1.21785

Wulandari, M., \& Asmawi, M. (2021). Hubungan Status Gizi dan Aktivitas Bermain melalui Keterampilan Gerak Dasar Anak Taman Kanak-Kanak. 5(2), 1706-1717. https:// doi.org/10.31004/obsesi.v5i2.965

Zakaria. (2014). Media Audio Visual Berpengaruh Terhadap Kecerdasan Kinestetik Anak Kelompok B RA Anak Sholeh Colomadu Karanganyar Tahun Ajaran 2013/2014. Universitas Muhammadiyah Surakarta.

Zulfah, U. (2019). Penerapan Gerakan Senam Ceria Untuk Meningkatkan Minat Siswa Dalam Kegiatan Fisik Motorik Kelompok B di Pos Paud Terpadu Kartini Kota Surabaya. Motoric (Media of Teaching Oriented and Children), 3(1), 7-14. https://doi.org/10.31090/m.v3i1.868 